\title{
UTILIZATION OF ARCHIVE GEOPHYSICAL DATA FOR GEODYNAMICAL STUDIES IN THE SUDETES: EXAMPLE OF BĚLÁ FAULT ZONE (THE NÍZKÝ JESENÍK MTS.)
}

\author{
Lubomil POSPíŠIL ${ }^{1,2)}$ *, Jiří OTAVA ${ }^{3)}$ and Eva HUDEČKOVÁ ${ }^{3)}$
}

\author{
1) Institute of Geodesy, Faculty of Civil Engineering, Brno University of Technology, Veveři 95, 60200 Brno, Czech Republic \\ ${ }^{2)}$ Department of Geological Engineering, Faculty of Mining and Geology, V̌́B-Technical University of Ostrava-Poruba, Czech Republic \\ ${ }^{3)}$ Czech Geological Survey, Division of Informatics and Geological Division, Leitnerova 22, 65869 Brno
}

*Corresponding author's e-mail: pospisil.1@fce.vutbr.cz

\section{ARTICLE INFO}

Article history

Received 31 January 2019

Accepted 20 June 2019

Available online 30 July 2019

Keywords:

Recent vertical movements

GNSS networks

Geophysics

Bělá fault

Reflection seismic

\begin{abstract}
Geophysical data are used not only, in geological mapping, exploration of mineral resources, hydrogeology, but are also important for other branches such as environmental protection, civil engineering and archeology. That is why, within the project CzechGeo/EPOS (www.czechgeo.cz), geophysical data access is solved as a separate topic under the guidance of the Czech Geological Survey (hereinafter CGS). In accordance with the current needs of national and international activities (INSPIRE, EPOS, IAGA), an inventory of available data, its consolidation and harmonization according to national and international standards is conducted. The aim is to store securely and permanently valuable data, which in many cases cannot be reinstated.

On the example from the Nízký Jeseník Mts. possible advantages and utilization of Archive data for mapping and verification of the movement tendencies gained from GNSS networks - EPN, EAST SUDETEN and MORAVA are demonstrated.

Very valuable information for the interpretation of structural and tectonic conditions is provided by geophysical data (seismic reflection profiles, gravity and magnetic data, etc.) in the area of interest, especially in terms of monitoring the main fault systems and the character of the basement structures.
\end{abstract}

\section{INTRODUCTION}

Using an example from the Nízký Jeseník Mts. we demonstrate a successful usage of geophysical Archive data in mapping and verification of recent crustal movement tendencies that follow from data gained within the EPN, EAST SUDETEN and MORAVA GNSS networks. The area under discussion is covered by these three geodetic networks that monitor long-term recent Earth's surface movement tendencies in northern Moravia. The monitoring results of approx. 20 years lead to a conclusion of significant horizontal dextral displacement tendencies that are concentrated along the Bělá fault system (Buday et al., 1995 - Fig. 1). The continuation of the latter towards the NW is associated with the Marginal Sudetic Fault.

In the paper, we aim at showing of this structure verification of the results of the GNSS monitoring. Another aim is to calculate the possible depth level of the source generating the observed tectonic motions.

Highly valuable information is additionally provided by geophysical data (seismic reflection profiles, recent vertical movements (RVM), earthquake foci IEP MU, GRAV/MAG data, etc.).

The main goal of the paper remains interpretation of structural and tectonic features and their recent dynamics in the area of study, based mostly on data from the monitoring of the main fault systems and on characteristics of the basement structures.

\section{GEOLOGICAL SETTINGS}

The area with the most intensive recent movements tendencies (Fig. 1) is located in the Moravian-Silesian part of the European Variscan orogen; more precisely of its youngest Culm facies (D-LC), easternmost part. Geographically it belongs to the Nízký Jeseník Highlands and geologically and stratigraphically to the Lower Carboniferous (Viséan) sequence of so the called Culm facies. Generally the western parts of area are composed of prevailing pelitic turbidites, while greywackes prevail in the east (Fig. 1). The Culm facies sediments tectonically overlie those of the Devonian carbonate facies as proved by the borehole Potštát 1 (Č́žek and Tomek, 1991).

Let us summarize the present state of knowledge, especially that one concerning structural geology and thermal history. Since the evaluation of seismic reflection profiles and the borehole Potštát-1 (Č́žek and Tomek, 1991) the model of thin-skinned southeasterly tectonic transport within the fold-andthrust belt has been accepted. Most recent work regarding thermal history of the Culm basin (Jirman et al., 2018) brings about a model based on study of the Culm facies (D-LC) vitrinity reflectance in surface 


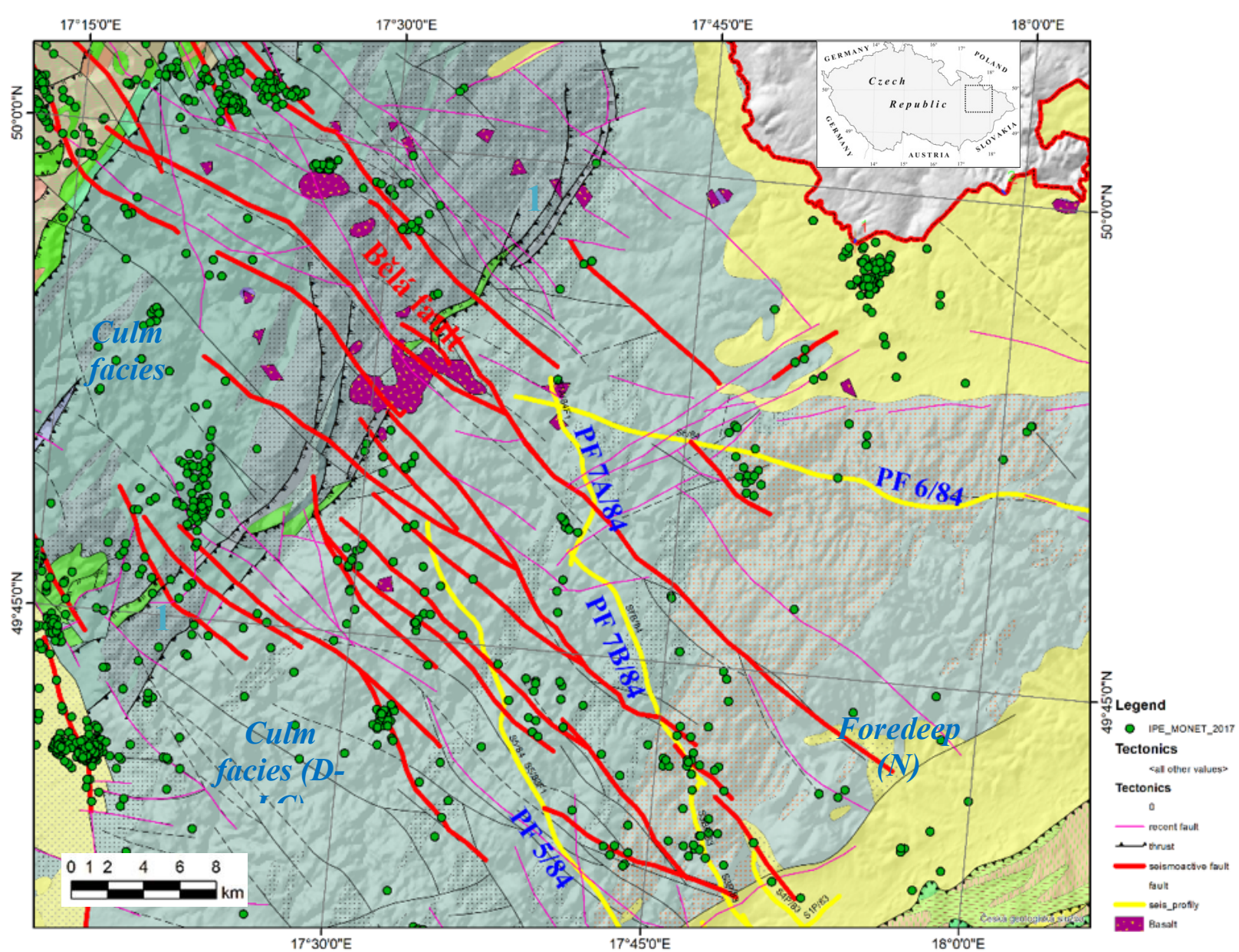

Fig. 1 Map of the Culm area with location of the Bělá fault system, complemented by recent earthquake data (1996 to 2017 - Sýkorová et al., 2018). Explanations: N- Neogene, D-LC- Devonian - Lower Carboniferous, violet color neovolcanics, 1- Šternberk-Horní Benešov tectonic zone

and borehole (Potštát-1) samples. The supposed maximum paleotemperatures calculated were 260 $285^{\circ} \mathrm{C}$ for paraautochtonous limestone sequences and $310-400{ }^{\circ} \mathrm{C}$ for tectonically overthrusted sediments of the Culm facies. The estimated primary thickness of a sedimentary pile of the Culm facies rocks corresponding with the measured vitrinity reflectance, and thus the calculated paleotemperatures, exceeds $7 \mathrm{~km}$. According to Jirman et al. (2018) the maximum thermal maturity of the flysch deposits was aquired prior to the Variscan overthrusting, i.e. before $325 \mathrm{Ma}$. The Devonian carbonate complex reached its maximum thermal maturity already after the overthrusting of the partly eroded flysch sequence before $320 \mathrm{Ma}$.

\section{METHODOLOGY AND PROCESSING}

We used the following data processing, verification and analysis techniques to evaluate movement tendencies and their interpretation:

- Processing of an archive data from CGSGEOFOND Prague database (geological maps, wells and geochemical data, seismic reflection profiles in SGY versions, radiometric map of the Czech Republic (Manová and Matolín, 1995))

- Geophysical data of Geofyzika a.s., Brno (gravity and magnetic data, seismic reflection profiles)

- Catalog of Earthquakes (Institute of Physics of the Earth, Masaryk University (IPE MU), USGS))

- GNSS data from available networks (Švábenský et al., 2012; Pospíśil et al., 2017; Kaplon et al., 2014)

- Recent vertical movements data (Vyskočil, 1996)

Archive Data - The geophysical database of the CGS, department GEOFOND includes the results of geophysical measurements (surveys) in the territory of the Czech Republic, which was mostly taken by the former Geofyzika Brno company from state budget funds from the end of World War II to the end of 2003. Now, they are mostly updating new data from air-borne measurement and gravimetric mapping projects financed mainly the Ministry of the Environment of the Czech Republic (hereinafter MŽP ČR).

Since 2018, as part of the CzechGeo/EPOS project, this data will be gradually made available through map applications.

\section{DATA USED FOR VERIFICATION AND REINTERPRETATION}

One of important tasks was to verify the movement trends. Suitable data and criteria were 


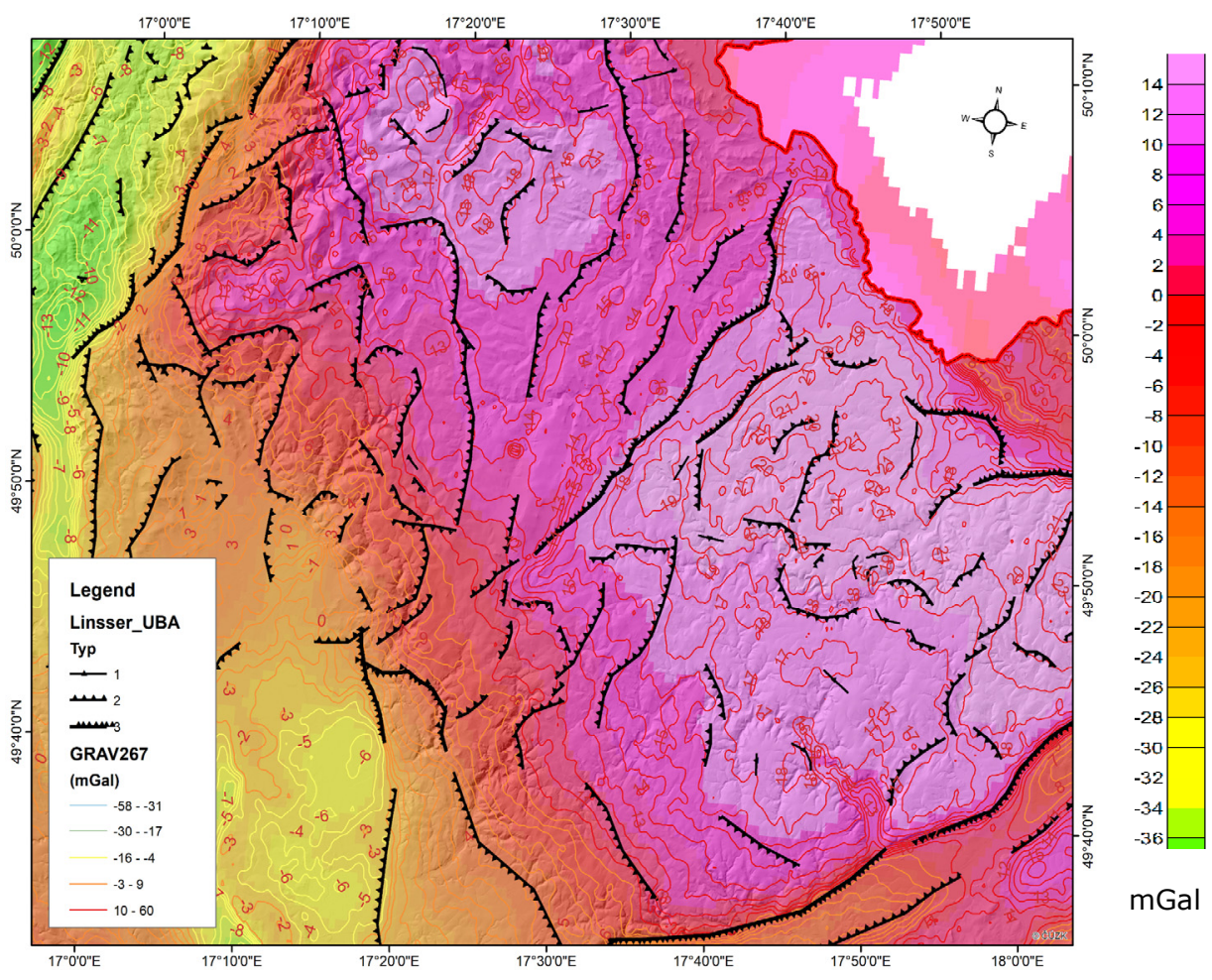

Fig. 2 Demonstration of combination of the Map of Complete Bouguer anomalies, compiled for the reduction density $2.67 \mathrm{kgdm}^{-3}$ archived in GEOFOND Database with the derivated map of Verticaal density boundaries (Linsser indications of density contacts). The contour interval is $21 \mathrm{mGal}$. The Linsser indications represent spatial and material characteristics of density contact, approximating it by a vertical fault model (Linsser, 1967). The intensity of the Linsser indication is given by the product $E \times C$, where $E$ is the amplitude of the gravity effect and $C$ is the coincidence between the observed gravity anomaly and the gravity effect of the fault model. Black line segments show the positions of density contacts at the depth of $1 \mathrm{~km}$.

collected and interpreted to prove faults within the studied area and to explain their character and kinematics. Geomorphological studies and data (Roštínský et al., 2013; Grygar and Jelínek, 2000) completed with geophysical data of sufficient aerial extent were involved to submit the geological model.

\section{GEOPHYSICAL DATA}

Gravity Data - A detailed gravity map of Complete Bouguer anomalies, compiled for a reduction density of $2.67 \mathrm{kgdm}^{-3}$, on a scale of 1:25 000 for the entire Czech Republic, does not provide more detailed information about the NW-SE tectonics. The main structural units of the Silesia and the Culm area with their effects can be observed from the presented map (Fig. 2) and give the size of individual anomalies, they can be judged by their powers. Horizontal gravity gradients or vertical density interfaces (Linsser, 1967) dominate mainly N-S and NE-SW directions. That's why we used gravity maps for verification at least.

Magnetic Data - Magnetic map of $\Delta \mathrm{T}$ anomalies of the Czech Republic has been compiled on the basis of measurements made with airborne proton magnetometer with digital registration at $80 \mathrm{~m}$ above the terrain surface (aprox. $55 \%$ of the CR area), distance of flight lines - $250 \mathrm{~m}$, period measurements form 1974 to 2004 (Gnojek et al., 2000). Final version of map of anomalous field delta $\mathrm{T}$ of the Czech Republic were processed for epoch 1981 (Fig. 3). All above discussed geological and tectonic problems can be followed in the Magnetic map processed by Oasis Montaj SW.

Seismic Data - The map layer "the Seismic reflection profiles" shows only those reflective seismic profiles that have been registered with digital seismic apparatus, and seismic data has been stored either in the SEG-Y international format or in the corporate CGG format. This condition is fulfilled by reflective seismic profiles from 1971 to 1994 , which were measured and processed by the former company Geofyzika Brno from the state budget.

Access to own seismic data, either in digital format (SEG-Y or CCG format) and raster format (tiff), is only possible with the consent of the Department of Geology of the Ministry of the Environment of the Czech Republic, as the owner of the data. For commercial customers, "lending" is tied to the existence of a reconnaissance territory and is charged. The results of other seismic measurements, such as refractive seismic profiles (regardless of type of registration) and reflective seismic profiles with analogue registration, are not included in the map layer "Seismic reflection profiles" and are only available in the form of archival reports. There is possibility to attach a layer of seismic well logs measured on the boreholes near the reflection profiles, but these do not exist for our area.

Figure 4 shows the reflective seismic profile used 7A/84. This profile intersects almost perpendicularly the southern part of Bělá fault zone. 


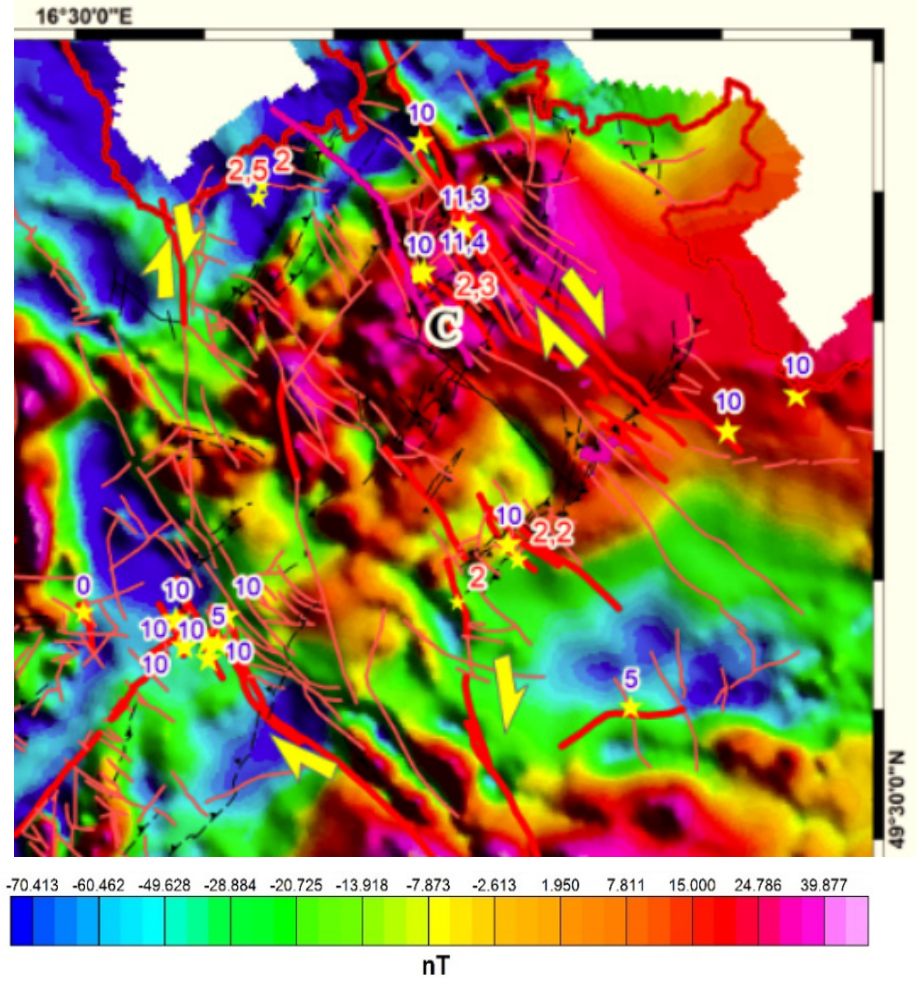

Fig. 3 Map of magnetic anomalies $\Delta \mathrm{T}$ (the difference between the measured magnetic field inductance value and the IGRF field reference value for the epoch 1981.0). Map is complemented with recent earthquakes epicentres (yellow stars (Sýkorová et al., 2018)) with magnitude values (M - red) and estimated depths of the hypocentres (blue).

Earthquakes Foci - The available earthquake foci come from the worldwide USGS Earthquake Catalog and regional earthquake catalogs by the Institute of Physics of the Earth at the Masaryk University in Brno (IPE MU, incl. events recorded by Sýkorová et al. (2018) and the Institute of Geophysics of the Czech Academy of Sciences (IG CAS). In the Nízký Jeseník Mts., the earthquakes commonly reach a local magnitude (M) of 1-3 with estimated depths of $\sim 1-$ $12 \mathrm{~km}$ at $\mathrm{W}$ from the Šternberk - Horní Benešov fault system and depth $14-24 \mathrm{~km}$ on the E of the Culm area.

Earlier, the illustration and interpretation of the earthquake epicenters and hypocenter depths were collected for the regional maps (Kárník et al., 1984a, 1984b; Schenková and Kárník, Eds., 1985), in case of known historic macroseismic fields supplemented with an estimation of asymmetric seismic energy attenuation related to local tectonic structures (Procházková and Kárník, 1978; processed after the methodology by Schenk et al., 1989), and in some places also with calculated focal mechanisms (Havír, 2004; Špaček et al., 2015, 2006).

GNSS Data on Moravia Territory (EPN, MORAVA, EAST SUDETEN, CZEPOS) - Results of the mapped horizontal movement tendencies of the Northern Moravia area offer in the recent period the following GNSS networks:

Epoch geodynamic networks:

- SNĚŽNÍK

- MORAVA

- EAST SUDETEN,

\section{- $\quad$ HIGHLANDS}

Permanent networks:

- EPN, CZEPOS, VESOG, GEONAS (public and research networks),

- TOPNET, VRS Now Czech, GEOORBIT (commercial private networks)

For the analyses of the area of interest the MORAVA, EAST SUDETEN and CZEPOS networks were used, only. Data were processed from time period/interval mentioned bellow.

The existing epoch geodynamic networks are characterized by many common features, notably by a careful selection of point locations in terms of the optimal observation conditions and assumed tectonic phenomena. The effort to stabilize sites embedded in the rock substrate or stable objects with a fixed base, allowing for forced centring of the receiving antennas, is also important. It has been desirable to use unmodified instrumentation at individual points. Overview of position of all GNSS networks points is in Figure 5 and the brief characteristics of the individual networks are as follows:

- SNĚŽNÍK - built in 1992 in cooperation between two academic institutions: Wroclaw University of Environmental and Life Sciences (PL) and Brno University of Technology (CR). Its basic research results were presented by Švábenský et al. (2012);

- MORAVA - larger network established in 1994 under joint research activities of the VŠB Technical University of Ostrava and Czech Technical University in Praha to study tectonics of crustal structures in the Bohemian Massif - 


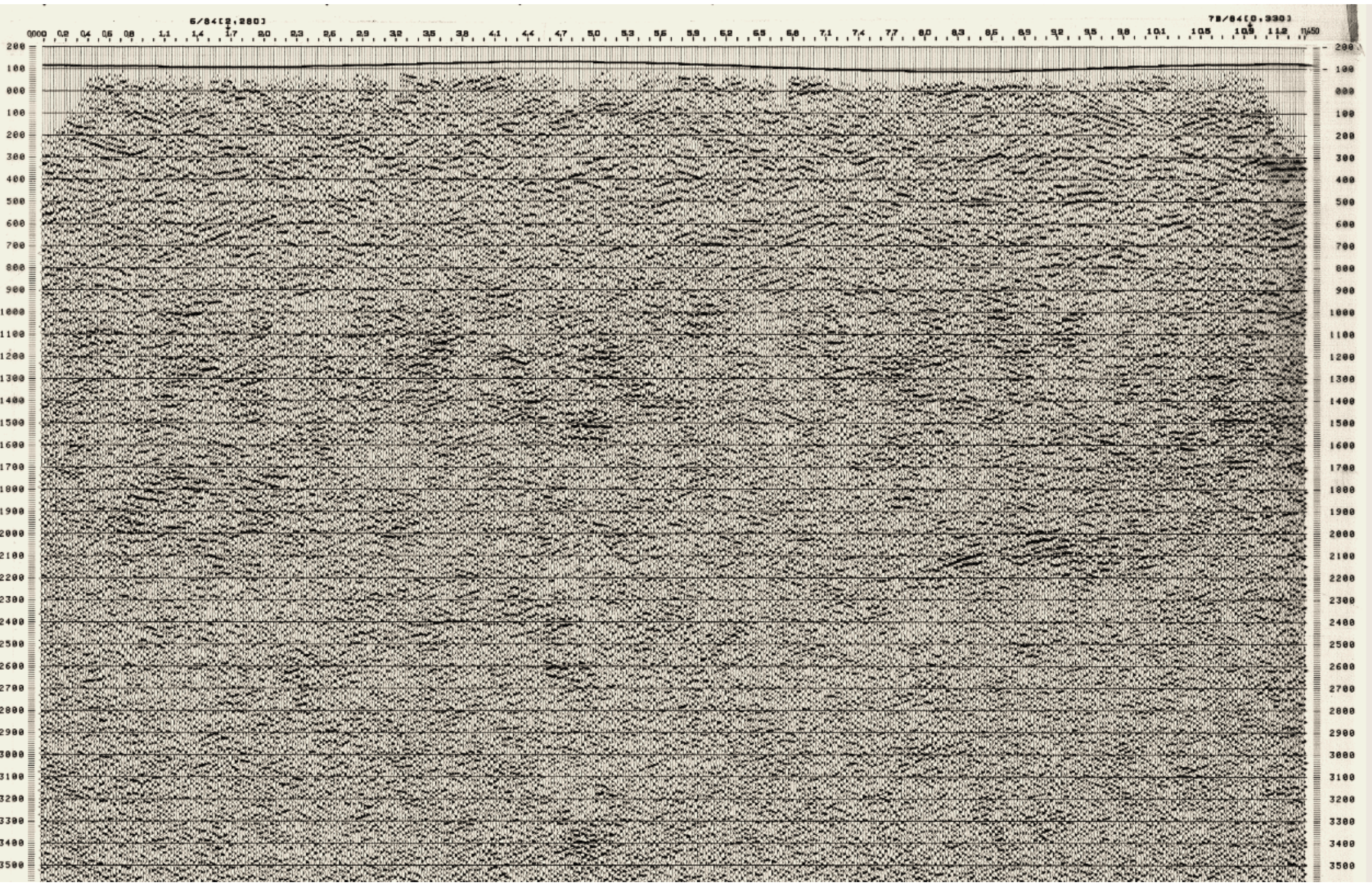

Fig. 4 Seismic reflection profile 7A/ 84, type Slalom Line SL. fold 24, datum plane 300m, scale 1:20,000, OGEOFOND-CGS Praha. 


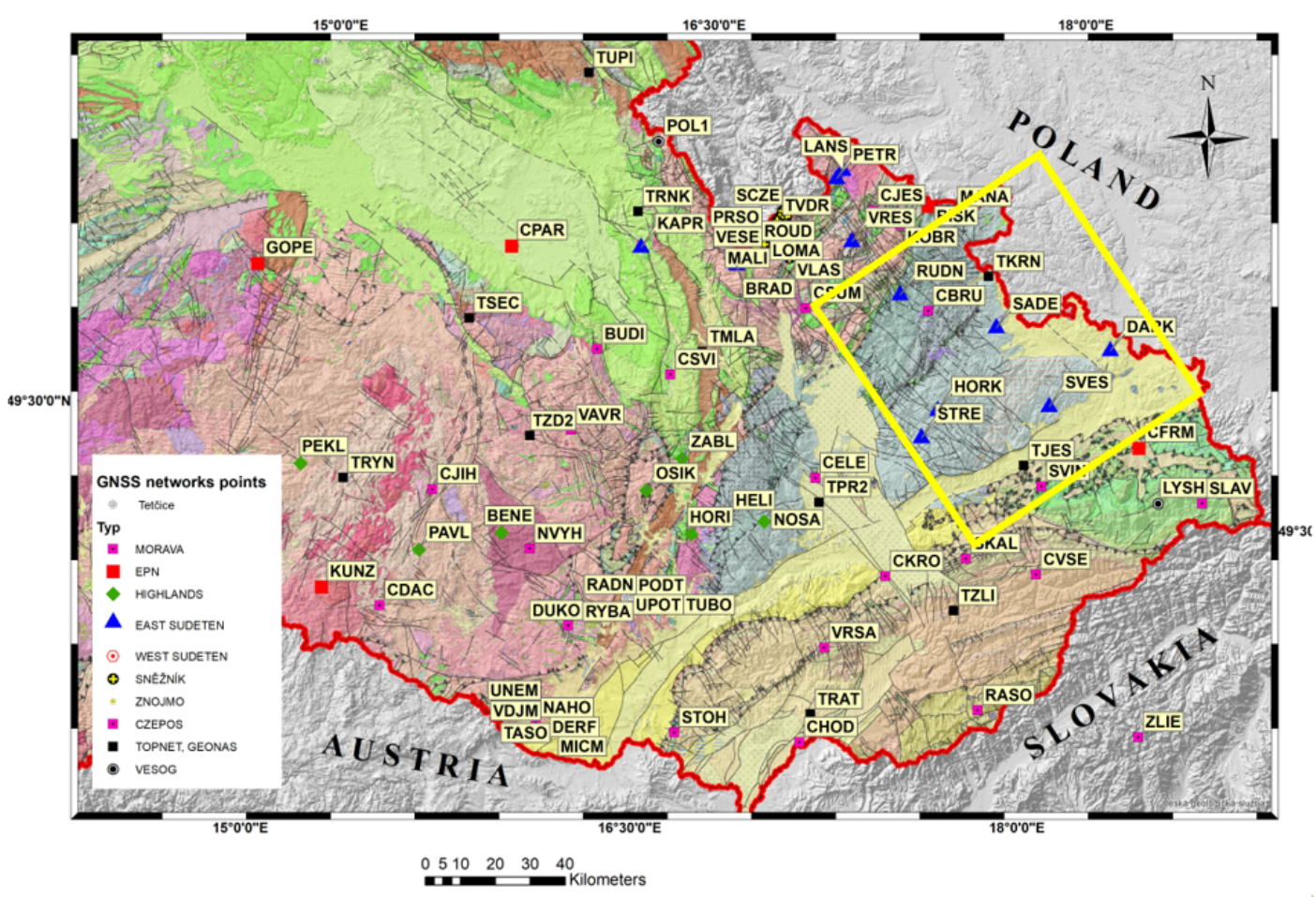

Fig. 5 GNSS points in the Moravian area. Part of Culm complex is limited by yellow rectangle. In background of image is Geological map of Czech Republic (Cháb et al., 2007).

Western Carpathians contact area (Foldyna et al., 1997), later used and remeasured by the Institute of Geodesy at the Brno University of Technology (IG BUT);

- $\quad$ EAST SUDETEN - built in 1997 by the Institute of Rock Structure and Mechanics, Czech Academy of Sciences (IRSM CAS to investigate fracture structures in the NE part of the Bohemian Massif (Schenk et al., 2002);

- HIGHLANDS - established in 2005 by the Institute of Rock Structure and Mechanics, Czech Academy of Sciences to study the mountainous areas in the E part of the Bohemian Massif (Schenková et al., 2009).

A few results from the WEST SUDETEN network ( $N$ part of the Bohemian Massif; established by the IRSM in 2001; Schenk et al., 2006; Kaplon et al., 2014) were also applied. Generally, results from 10-20 years lasting periods of repeated measurements could be taken into account in case of particular networks.

Since 1994, epoch GNSS measurements in the Czech part of the SNĚŽNÍK network in regular annual campaigns have been carrying out by the IG BUT (Švábenský et al., 2012). The same institute also participated in the first three campaigns in the MORAVA network (1994-1996), and in 2009-2015 it performed almost complete (except for two points) re-measurement of this network (primary information in (Roštínský et al., 2013; Švábenský et al., 2014, 2011). Moreover, observations at selected points of the EAST SUDETEN and HIGHLANDS networks were also performed (Pospíšil et al., 2017) indicating recent movements along important active fault zones in the central part of the Eastern Bohemian Massif (EBM). The main focus of the research was on the structures reaching $\sim 1 \mathrm{~mm}$ annual velocities or even more (max. $2 \mathrm{~mm} /$ year) including the Diendorf-Čebín tectonic zone (DCTZ (Roštínský et al., 2013), Železné hory - Tišnov tectonic zone ZHT (Švábenský et al., 2014) and wider area of the northern Boskovice Graben (Pospíśil et al., 2017). The studies significantly supplemented geological and geophysical data on these tectonic zones. For our purposes, the presented GNSS results from the Moravia network (MN - Pospíšil et al., 2017), which were supplemented with data from the East Sudeten Networks (ESN - Schenk et al., 2002), Sněžník (SN Švábenský et al. 2012) and marginally Highlands (HN - Schenková et al., 2009) and also with latest unified and uniformly reprocessed data of Kaplon et al., (2014).

Recent Vertical Movements (RVM) - The study of the Recent movements of Earth crustal blocks through geodetic measurements has been carried out and ensured on the territory of the Czech Republic through the Research Institute of Geodesy, Topografy and Cartografy (VÚGTK) since the end of the 1950s.

For the purpose of verifying the horizontal movement tendencies, we also used the results of vertical velocities $w_{0 \mathrm{i}}$, obtained from repeated leveling from 1974-1984, which were equalized for the whole territory of the former Czech Republic (Vanko and Vyskočil, 1987). Annual rates have been established with respect to the Basic reference point ŽELEŠICE (SW from Brno). The leveling network was densified throughout the Czech Republic and results compiled to the map at the original scale of 1: 200,000, with an isolation interval of $0.1 \mathrm{~mm} /$ year. The reduced version of this map to a scale of 1 : 1000000 (Vyskočil, 1996) was digitized and modified to a simplified and clearer version but with 


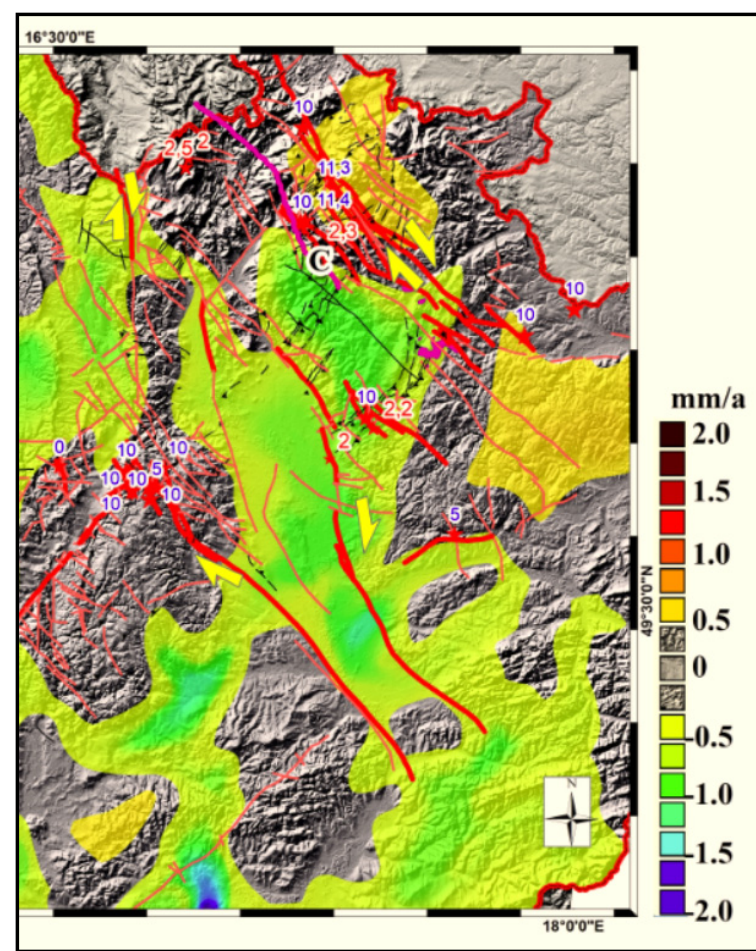

Fig. 6 Map of Recent vertical velocities (mm/a (Vyskočil, 1996), modified by authors). In the area of interest, vertical motion tendencies of tectonic blocks dominate. Noth of the Bělá fault there are positive tendencies, whereas negative tendencies prevail south of it. Tectonic block with Culm facies on the East area shows relative uplift. C possition of Bělá fault zone

the same resolution, supplied by geological faults (Czech Geological Survey Prague). The underlying layer was used the illuminated radar relief (SRTM DEM data - CNASA/USGS - illumination 315 W/elevation $45^{\circ}$ (Fig. 6) and DMR 4D (web of the State Administration of Land Surveying and Cadastre (CUZK)). This was the way to observe (to show) the relation between morphological structures and active zones with vertical move trends (Fig. 6).

\section{RESULTS - GEODYNAMIC DATA ANALYSES}

The Culm area has one of the highest movement tendencies in Moravia. The observed movements between the points CBRU, BISK, SADE in the north and STRE and HORK points in the south range between $-2.1 \mathrm{mmy}^{-1}$ to $-0.4 \mathrm{mmy}^{-1}$. When comparing with known active fault systems in a given area, it has been shown that the Bělá tectonic system plays a dominant role here (Buday et al., 1995). The character of the movements, not only according to the results of GNSS measurements (Kaplon et al., 2014), but also according to seismological data (Sýkorová et al., 2018; Špaček et al., 2015), is interpreted as dextral and is distributed among several segments of the fault system.

The basic knowledge, that can be observed from velocity vectors (Kaplon et al., 2014), is that while in the Silesian area all the elements of motion are bound to the Sudetic Marginal fault and the Běla fault zone, behind the Šternberk-Horní Benešov fault system (Fig. 1) is the main movement of blocks shifted to southern blocks of the continuing the Bělá fault system (Figs. 3, 4, 7). It is confirmed also by earthquake foci which are concentrate along and near to Haná fault (northern margin of the the Upper Moravian Basin (Fig. 7).

We have used the reflection seismic profiles from the CGS - GEOFOND database to verify and especially to identify potential active faults on which these recent movements could take place. Because of the orientation NW-SSE, we have chosen profile 7A/84 (Kolejka et al., 1985 (Fig. 8)), since its direction towards the fault system of Bělá is the most complex. The analysis of the other profiles (5/84, 6/84 and 7B/84 (Č́žžek and Tomek, 1991) shows that the basic structural-tectonic conditions could be fairly well interpreted, but the detailed tectonic definition of the individual breaks is very complicated due to the strong shrinkage. Nevertheless, it has been possible to find fundamental changes in the orientation and inclination of individual reflexes and, in particular, to define the main and fundamental structural horizons in this area. First of all, it has been shown, in accordance with the previous interpretations (Č́žžek and Tomek, 1991), that in the section there are clearly different orientations of the structures at the top and bottom of the cut.

\section{DISCUSSION AND CONCLUSIONS}

The presented study evaluating results of the GNSS measurements, additionally confronted with regional recent vertical movements and a number of geomorphological and geophysical indicators, provides a lot of new information about older geodynamic and recent kinematic conditions of this area in its most complicated part, just represented by the Culm area. Application of the complex approach correlating comparable outputs of more disciplines led to more reliable description of significant basic or derived structural features. The previous structural, morphotectonic and geophysical analyses (Badura and Rauch, 2014; Grygar and Jelínek, 2000; Havíŕ, 2002, 1999; Jelínek, 2003; Kárník et al., 1984; Labák and Bouček, 1996; Lenhardt et al., 2007; Pazdírková et al., 2015; Procházková and Kárník, 1978; Schenk et at., 1989; Skácelová and Haviŕ, 1999; Špaček, et al. 2015, 2008, 2006; Vyskočil, 1996; Zedník et al., 2001) were especially considered at revealing the spatial patterns of linear landforms and their interrelationships with regional geophysical fields. Many of these works also included data on historic and primarily recent seismic activity, its focal mechanisms or earthquake patterns, eventually even information about neovolcanite occurrences or $\mathrm{CO}_{2}$ emissions, i.e. phenomena evidencing true recent geodynamic activity.

Whereas the GNSS results are related to surface block boundaries, the driving factors are to be searched in deeper parts of the fault structures. Thus, even at the clearly linked cases it is difficult to exactly estimate the approximate depth level at which the respective movement is currently generated and determine in more detail its form (commonly steep thrust zone or deep-seated fault). 
Therefore, the controlling process of suggested interpretations should include, besides evaluation of regional seismic data, also an assessment of available reflection seismic profiles running across the most active subareas that facilitate to define a geodynamical character of deep geological structures.

The correlation to the gravity, magnetic or radiometric boundaries appeared to be sufficient enough to reliable determine the main fault. Moreover, the collaborative application of all three disciplined predicts more important disruptions and linear fracture systems in the EBM than displayed in the avilable geological maps. When the location of geomorphological phenomena is additionally compared with the seismically active tectonic boundaries (Fig. 3), it is also indicated a high possibility of their generation in deeper parts of the crust.

The deduced model of the main active fault systems (Fig. 8) reflects not only surface structural plan of the Culm area. A reliability of the proposed geodynamical conception at the deeper structural levels is in case of the two problematic areas supported by a geological assessment of severel reflection seismic profiles (CGS - Geofond): 7A/84, 6/84-83, 5/83-84 (Culmian Complex of the RHH).

The former explanation (Buday et al., 1995; Č́źžek and Tomek, 1991; Hladil et al., 1990) were focused on internal structure of the local Culmian Complex, especially its variable thickness and degree of deformation. The new model (Fig. 8) aimed at character of the deep basement of the Culmian Complex and more detail inner in the Culmian complex itself:

- The seismic profile reflects partly the fold and thrust structures in the near surface parts.

- It starts as a "flower structure“" in the $\mathrm{W}$ and continues most probably as SE-vergent

- Bělá fault system is the youngest one, displaces the variscan systems of first and second order and seems to show an asymmetrical flower structure system

- There is an appartent difference in the structural image between the upper segment (above master decollement) and lower segment (central and western part below the master decollement, the „carbonatee complex“)

- There are common dome structures within the tectonic slices of the carbonate complex.

- Due to the changing orientation (trajectory) of the $7 \mathrm{~A}$ profile (from NNW-SSE to NNE-SSW) the section does not reflect properly the sense of tectonic transport

- Pure limestones of the Macocha Formation display specific pattern in any part of seismic profiles. It is well rocognizable and distinct from other lithologies.

Nevertheless, a few fundamental questions remain unanswered. Above all, answer the question of what is in the basement of the Culmian facies? Is it always metamorphic crystalline basement, or are there some remnants of the Cambrian siliciclastics known from Southern Moravia and Southern Poland boreholes?

It can be said that archival data continue to provide invaluable data for new interpretations, with minimal cost.

\section{ACKNOWLEDGEMENTS}

The paper was processed under the BD 12500028, BD 1240001012 and BD 12300008 projects of the Brno University of Technology and was supported by the Ministry of Education, Youth, and Sports of the Czech Republic (grant project SGS SP2018/33). Geological part of the paper has been processed on the Geological Division of the Czech Geological Survey, Department of Regional Geology of Moravia.

All students of the Geodesy Institute of the Brno University of Technology are primarily thanked for their participation in the numerous field GNSS campaigns, which have contributed significantly to the results of this work.

\section{REFERENCES}

Badura, J. and Rauch, M.: 2014, Tectonics of the Upper Nysa Kłodzka Graben, the Sudetes. Geol. Sudet., 42, 137-148.

Buday, T., Duurica, D., Opletal, M. and Šebesta, J.: 1995, Importance of the Bělá and Klepáčov faults system and its continuation into the Carpathians. Uhlí-RudyGeol. Průzk. 2, 275-282, (in Czech).

Cháb, J., Stráník, Z. and Eliáš, M.: 2007, Geological map of the Czech Republic 1:500,000. Czech Geological Survey, Praha.

Č́ižek, P. and Tomek, Č.: 1991, Large-scale thin-skinned tectonics in the eastern boundary of the Bohemian Massif. Tectonics, 10, 2, 273-286. DOI: $10.1029 / 89 \mathrm{TC} 03241$

Foldyna, J., Ratiborský, J., Kabeláč, J., Blažek, R., Grygar, R., Novák, J., Schenk, J., Gavlovský, E., Tyrner, M., Kubečka, E. and Mikulenka, V.: 1997, Final report of the GA CR project No. 105/94/1124: Monitoring the supracrustal blocks movements at the Czech Massif and Alpine-Carpathian Arc border by Global Positioning System (GPS) method. Unpublished research report, VŠB - Technical University, Ostrava and Czech Technical University, Praha, (in Czech).

Gnojek, I., Mutlová, A. and Dědáček, K.: 2000, Aeromagnetic map of the Czech Republic based on the grid of data $250 \mathrm{~m} \times 250 \mathrm{~m}$. Ministry of Environment of Czech Republic, Archive of GEOFOND-CGS Praha

Grygar, R. and Jelínek, J.: 2000, Alpine and Variscan Orogeny Belts interaction - an example of morphostructural analysis (Moravosilesian r egion of the Bohemian Massif). Geolines, 10, 23-24.

Haviŕ, J.: 1999, The fabric of the Culm conglomerates in the eastern parts of the Nízký Jeseník and Drahany Uplands (eastern margin of the Bohemian Massif, Czech Republic). Geol. Sudetica, 32, 1-11.

Havír, J.: 2002, Recent tectonic activity in the area northwards of Šternberk (Nízký Jeseník Mts.) Present knowledge. Acta Montana, Ser. A, No. 20(124), 97-104.

Havír, J.: 2004, Orientations of recent principal stress axes in the Jeseníky region. Acta Geodyn. Geomater., 1, No. 3(135), 49-57. 

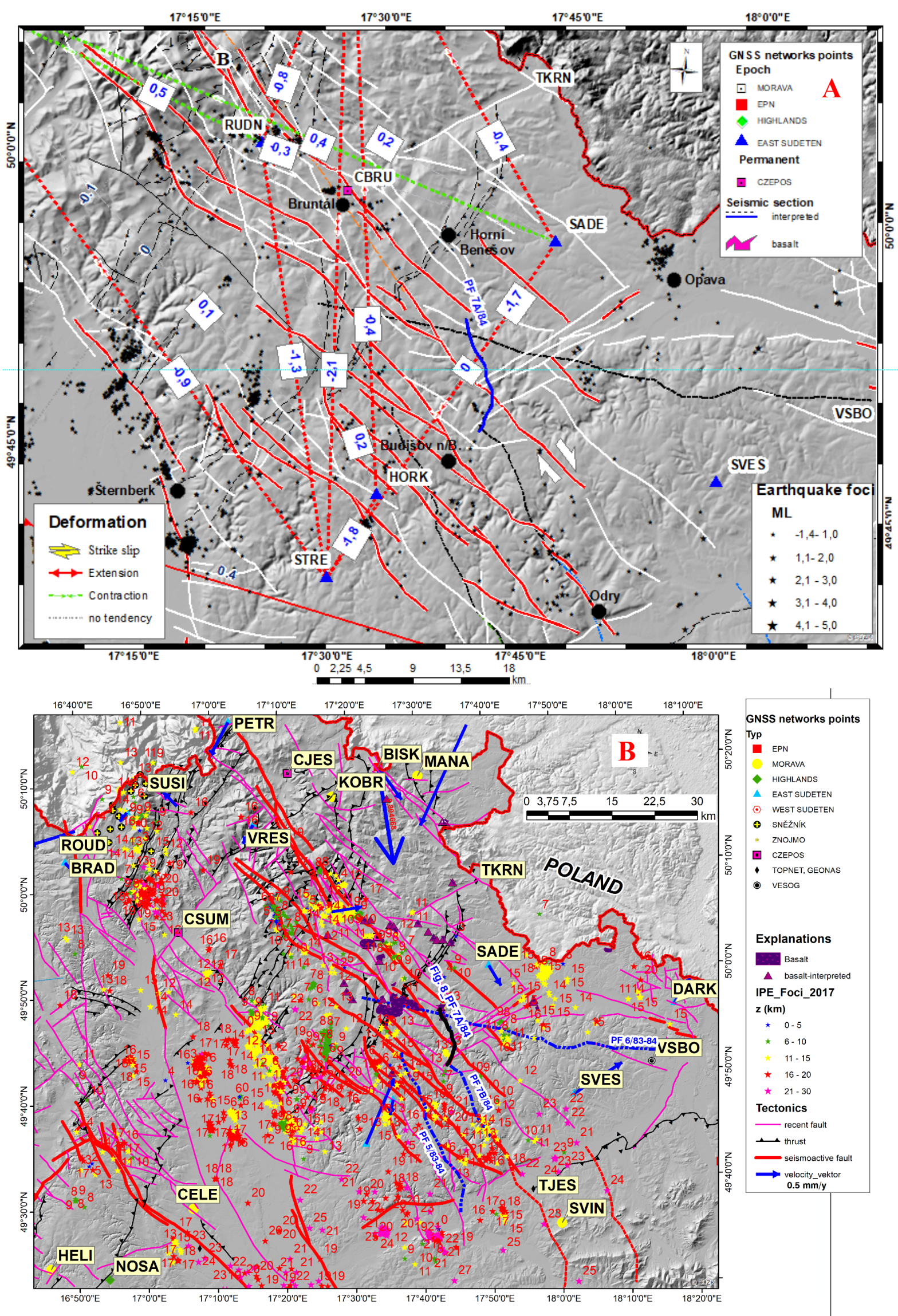

Fig. 7 The results of GNSS measurement of movement tendencies in the area of Nízký Jeseník, built by the Culmian facies (Devonian, Lower Carboniferous), supplemented by interpreted recent faults and earthquake foci. The figure A on the top is supplied by available seismic reflection profiles. The values between individual points are relative differencies.

In the figure B - on the bottom are the earthquakes with depths of hypocenters - in the western part of the Culm area are depths between 10 to $14 \mathrm{~km}$, on the eastern edge -16 to $24 \mathrm{~km}$. Blue arrows are velocity vectors from GNSS measurements (Kaplon et al., 2014), blue letter A - Šternberk-Horní Benešov tectonic zone. 

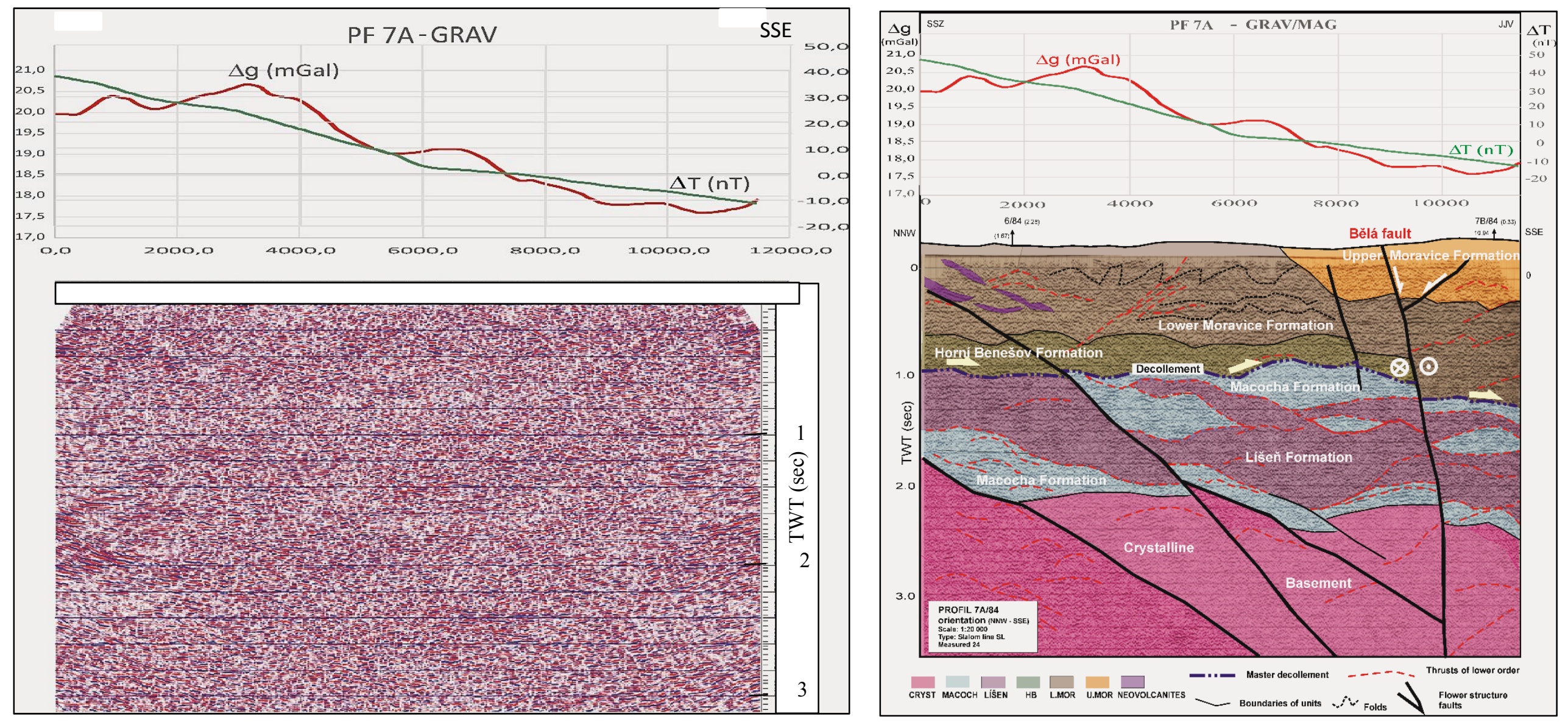

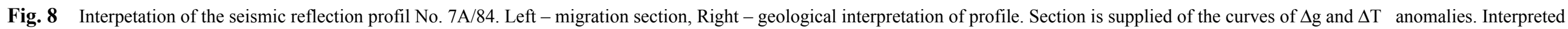
neovolcanic basalts sugges presence of the basaltoid complex Velký and Malý Roudný, west of the profile. 
Hladil, J., Chmelík, F., Ďurica, D., Čepeljugin, A.B. and Namestnikoy, J.G.: 1990, Prospect of the Paleozoic reef structures at the SE slope of the Bohemian Massif. MS-ÚÚG, Praha, $131 \mathrm{pp}$.

Jelínek, J.: 2003, Morphotectonic analysis of mutual structural relationships at the contact of variscan and Alpine orogeny belts - Moravosilesian region. Ph.D thesis, VŠB, Technical University Ostrava, (in Czech).

Jirman, P., Geršlová, E., Kalvoda, J. and Melichar, R.: 2018, 2D basin modelling in the Eastern Variscan Fold Belt (Czech Republic): Influence of thrusting on patterns of thermal maturation. J. Pet. Geol., 41, (2), 175-188. DOI: $10.1111 /$ jpg.12699

Kapłon, J., Kontny, B., Grzempowski, P., Schenk, V., Schenková, Z., Balek, J. and Holešovský, J.: 2014, GEOSUD/SUDETEN network GPS data reprocessing and horizontal site velocity estimation. Acta Geodyn. Geomater., 11, No. 1(173), 65-75.

Kárník, V., Procházková, D. and Brouček, I.: 1984a, Catalogue of earthquakes for the territory of Czechoslovakia for the period 1957-1980. Travaux Geoph., 29(1981), No. 555, 155-186.

Kárník,V., Schenková, Z. and Schenk, V.: 1984b, Earthquake activity in the Bohemian Massif and in the Western Carpathians. Travaux Geoph., 29(1981), No. 547, 9-33.

Kolejka, V., Havelková, V., Chudomel, J. and Kouřil, M.: 1985, Final Report on Reflex-Seismic Survey in the area of Nízký Jeseník Mts. Project "Research and prognoses of the hydrocarbon prospective nontraditional areas of Czechoslovakia". MS Archive of Geofyzika, a.s., Brno, 20pp, (in Czech).

Labák, P. and Brouček, I.: 1996, Catalogue of macroseismically observed earthquakes on territory of Slovakia. Geophys. Instit. Slov. Acad. Sci., Bratislava.

Lenhardt, W.A., Švancara, J., Melichar, P., Pazdírková, J., Havíŕ, J. and Sýkorová, Z.: 2007, Seismic activity of the Alpine-Carpathian-Bohemian Massif region with regards to geological and potential field data. Geol. Carpathica, 58, 4, 397-412.

Linsser, H.: 1967, Investigation of tectonics by gravity detailing. Geophys. Prospect, 4, 480- 515.

Manová, M. and Matolín, M.: 1995, Radiometric map of the Czech Republic 1:500,000. Czech Geological Survey, Praha.

Pazdírková, J., Zedník, J., Prachař, I., Krumlová, H. and Zacherle, P.: 2015, Earthquakes in Hostěradice in June 2014. Geol.Výzk. Mor. Slez., Brno, 61-65.

Pospíšil, L., Švábenský, O., Roštinský, P., Nováková, E. and Weigel, J.: 2017, Geodynamic risk zone at northern part of the Boskovice Furrow. Acta Geodyn. Geomater., 14, 1(185), 113-129. DOI: $10.13168 /$ AGG.2016.0033

Procházková, D. and Kárník, V., Eds.: 1978, Atlas of isoseismal maps, Central and Eastern Europe. Geophysical Institute, Czechoslovak Academy of Sciences, Praha.

Roštínský, P., Pospíšil, L. and Švábenský, O.: 2013, Recent geodynamic and geomorphological analyses of the Diendorf-Čebín Tectonic Zone, Czech Republic. Tectonophysics, 599, 45-66. DOI: $10.1016 /$ j.tecto.2013.04.008

Schenk, V., Cacoń, S., Bosy, J., Kontny, B., Kottnauer, P. and Schenková, Z.: 2002, The GPS geodynamic network EAST SUDETEN - five annual campaigns (1997-2001): Data processing and results. Acta Montana, Ser. A, No. 20(124), 13-23.

Schenk, V., Schenková, Z. Grácová M. and Kottnauer, P.: 2006, Preliminary site movements in the GPS West
Sudeten network. Acta Geodyn. Geomater., 3, No. 3(143), 45-51.

Schenk, V., Schenková, Z. and Pospíšil, L.: 1989, Fault system dynamics and seismic activity - two examples from the Bohemian Massif and the Western Carpathians. Geoph. Trans., 35, 1-2, 101-116.

Schenková, Z. and Kárník, V. (Eds.): 1985, Catalogue of earthquakes of Central and Eastern Europe. Unpublished research report. Geophysical Institute, Czechoslovak Academy of Sciences, Praha.

Schenková, Z., Kottnauer, P., Schenk, V., CajthamlováGrácová, M., Mantlík, F. and Kujal, R.: 2009, Investigation of the recent crustal movements of the eastern part of the Bohemian Massif using GPS technology. Acta Res. Rep. 18, 17-25.

Skácelová, Z. and Havír, J.: 1999, Earthquakes on the eastern margin of the Bohemian Massif recorded by the stations of the IPE Brno. EGRSE Journal, 5, 2, 1621.

Sýkorová, Z., Pazdírková, J. and IPE-MONET team: 2018, Catalog of natural earthquakes in the NE Czech Republic IPE-MONET, release 2018.

Špaček, P., Bábek, O., Štěpančíková, P., Švancara, J., Pazdírková, J. and Sedláček, J.: 2015, The NysaMorava Zone: an active tectonic domain with Late Cenozoic sedimentary grabens in the Western Carpathians' foreland (NE Bohemian Massif). Int. J. Earth Sci., 104, 4, 963-990. DOI: $10.1007 / \mathrm{s} 00531-014-1121-7$

Špaček, P., Sýkorová, Z., Pazdírková, J., Švancara, J. and Havír, J.: 2006, Present-day seismicity of the southeastern Elbe Fault System (NE Bohemia Massif). Stud. Geophys. Geod., 50, 2, 233-258.

Špaček, P., Zacherle, P., Sýkorová, Z., Pazdírková, J. and Havír, J.: 2008, Microseismic activity of the Upper Morava Basin and surroundings. Sbor. Věd. Prací VŠB-Tech. Univ. Ostrava, Ser. Staveb., 8, 287-295.

Švábenský, O., Pospíšil, L., Weigel, J., Roštínský, P. and Witiska, M.: 2014, Results of repeated measurements at the Železné hory-Tišnov Fault System surroundings. Acta Geodyn. Geomater., 11, 3(175), 211-223.

Švábenský, O., Weigel, J. and Pospíšil, L.: 2012, Geodynamic network Sněžník: reprocessing and analyses of satellite data in the Czech part over the period 1997-2011. Acta Geodyn. Geomater., 9, 3(167), 339-347.

Švábenský, O., Witiska, M., Ratiborský, J., Blažek, R., Pospíšil, L. and Weigel, J.: 2011, Preliminary results of repeated measurements in local geodynamic network Morava. Acta Geodyn. Geomater., 8, 3(163), 291-301.

Vanko J. and Vyskočil, P.: 1987, The map of vertical crustal movements in Czechoslovakia and its interpretation. J. Geodyn., 8, 2-4, 143-150.

DOI: $10.1016(0264-3707(87(90032-9$

Vyskočil, P.: 1996, Recent crustal movements, their properties and results of studies in the territory of Czech Republic. IN: Seismicity, neotectonics and recent dynamics with special regard to the territory of the Czech Republic. Research Institute of Geodesy, Topography and Cartography, Zdiby, 42, $15,77-120$.

Zedník, J., Pospíšil, J., Růžek, B., Horálek, J., Boušková, A., Jedlička, P., Skácelová, Z., Nehybka, V., Holub, K. and Rušajová, J.: 2001, Earthquakes in Bohemian Massif and surrounding regions in 1995-1999. Stud. Geophys. Geod., 45, 3, 267-282. 